\title{
Characteristics of the 14 April 1999 Sydney hailstorm based on ground observations, weather radar, insurance data and emergency calls
}

\author{
S. S. Schuster, R. J. Blong, R. J. Leigh, and K. J. McAneney \\ Risk Frontiers - Natural Hazards Research Centre, Macquarie University, Sydney, NSW 2109, Australia
}

Received: 26 May 2005 - Revised: 2 August 2005 - Accepted: 2 August 2005 - Published: 11 August 2005

\begin{abstract}
Hailstorms occur frequently in metropolitan Sydney, in the eastern Australian State of New South Wales, which is especially vulnerable due to its building exposure and geographical location. Hailstorms challenge disaster response agencies and pose a great risk for insurance companies. This study focuses on the Sydney hailstorm of 14 April 1999 - Australia's most expensive insured natural disaster, with supporting information from two other storms. Comparisons are drawn between observed hailstone sizes, radarderived reflectivity and damage data in the form of insurance claims and emergency calls.

The "emergency response intensity" (defined by the number of emergency calls as a proportion of the total number of dwellings in a Census Collection District) is a useful new measure of the storm intensity or severity experienced. The area defined by a radar reflectivity $\geq 55 \mathrm{dBZ}$ appears to be a good approximation of the damage swath on ground. A preferred area for hail damage is located to the left side of storm paths and corresponds well with larger hailstone sizes. Merging hail cells appear to cause a substantially higher emergency response intensity, which also corresponds well to maximum hailstone sizes. A damage threshold could be identified for hailstone sizes around $2.5 \mathrm{~cm}(1 \mathrm{~cm})$, based on the emergency response intensity (insurance claims). Emergency response intensity and claims costs both correlate positively with hailstone sizes. Higher claim costs also occurred in areas that experienced higher emergency response intensities.
\end{abstract}

\section{Introduction}

Climatologically, the Sydney metropolitan area experiences an average of 10 hailstorms per year with the hail season lasting from August to February. Hailstorms generally occur during the late afternoon between 02:00 p.m. and 06:00 p.m. In Sydney the most hail-prone suburbs are concentrated in

Correspondence to: S. S. Schuster

(sschuste@els.mq.edu.au) the most densely populated areas and corridors (Schuster et al., 2005).

Over the last 38 years, hailstorms have contributed over one third of the total insured costs caused by all natural hazards in Australia, with $75 \%$ of these losses occurring in the south eastern State of New South Wales (NSW) (Insert, Fig. 1) (Insurance Disaster Response Organisation, 2005). With an insured loss of approximately AUD 1700 million (EUR 1000 million; USD 1100 million) and total estimated economic costs of approximately AUD 2300 million, the Sydney hailstorm of 14 April 1999 ranks as the costliest natural disaster in Australian insurance history. Blong et al. (2001) considered this event to have an estimated return period of only 25 to 30 years based on the hail footprint and maximum reliable hailstone size $(9 \mathrm{~cm})$. Loss return periods for houses (vehicles) can be expected on average more (less) frequent than once in one hundred years (Blong et al., 2001). The Sydney hailstorms of 18 March 1990 and 3 October 1986 and the Brisbane hailstorm of 6 January 1985 also rank amongst the top ten insured losses in Australia in the period of record, 1967 to 2005 (Insurance Disaster Response Organisation, 2005).

The April 1999 hailstorm was outstanding from a climatological point of view because of large hailstone sizes, its evening occurrence, outside the hail season and during a time period of (statistically significant) lower hailstorm frequency. Moreover, the damage cost of this particular supercell storm is comparable to the costliest hailstorms worldwide, e.g. the April 2001 tri-state hailstorm that affected Kansas, Missouri and Illinois, USA and resulted in the most costly losses on record with USD 1900 million (Changnon and Burroughs, 2003); severe storms in 1998 in the Minneapolis - St. Paul area, Minnesota, USA that caused insured losses of USD 1350 million; the May 1995 Dallas - Ft. Worth hailstorm in Texas, USA with insured costs of USD 1135 million and the July 1984 Munich hailstorm in Germany that produced insured losses of USD 480 million (Munich Re, 1984; Heimann and Kunz, 1985). All monetary values refer to the year of storm occurrence. 


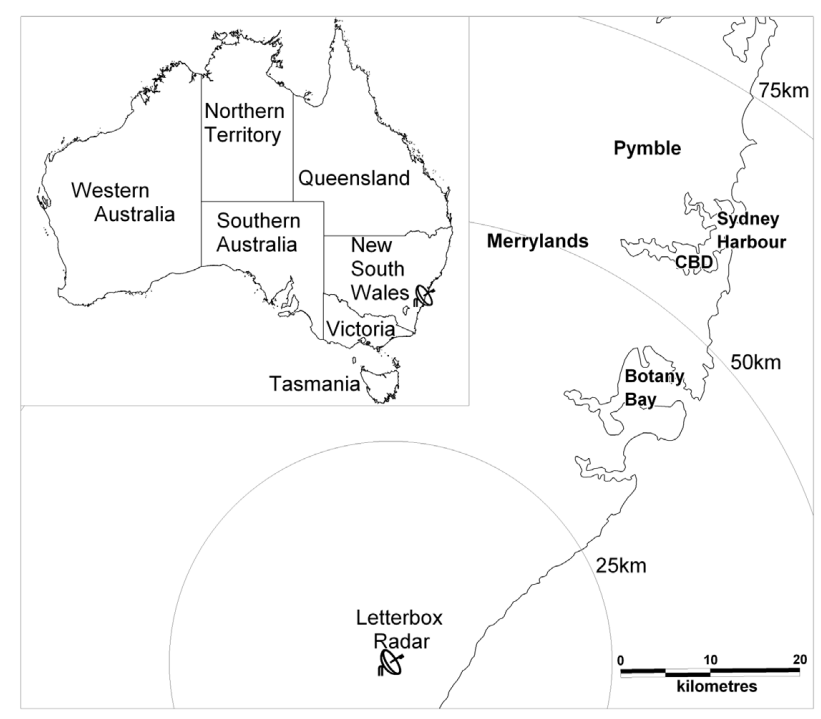

Fig. 1. Map of metropolitan Sydney with locations of mentioned suburbs and the Letterbox Radar (including circular distances with radii of $25 \mathrm{~km}, 50 \mathrm{~km}$ and $75 \mathrm{~km}$ ). Insert: Map of Australia including States and Territories.

Weather radar allows consistent measurements of potential hail intensity across large areas with high spatial and temporal resolution. Hailstone size observations for the April 1999 hailstorm are available (see next section). Combining these data on the hazard with damage data held by emergency services and the insurance industry results in the most detailed and comprehensive description of the impacts of this storm to date. This study draws comparisons and links between observed hailstone sizes, radar-derived reflectivity and damage data in the form of insurance claims and emergency calls. Supporting evidence from two other storms is also described.

\section{Data and methods}

Three storms are investigated in this study, with the main focus being the 14 April 1999 Sydney hailstorm due to its significance as well as the availability of relevant data. The following paragraphs describe the meteorological settings and available observational data including property damage information.

\subsection{Investigated storms}

\subsubsection{Sydney hailstorm April 1999}

This supercell thunderstorm struck the eastern suburbs of Sydney in the evening of 14 April 1999 (Zillman, 1999). Wind gusts of $85 \mathrm{~km} / \mathrm{h}$ were measured and the thunderstorm travelled at a speed of about $38 \mathrm{~km} / \mathrm{h}$ in a north north-easterly direction. The majority of the damage was located between Botany Bay and the CBD (Central Business District) (Fig. 1). Approximately 24000 homes, 70000 vehicles and 23 aircraft were damaged. AUD 10 million worth of tarpaulins and
$9600 \mathrm{~km}$ of rope were used to make buildings weatherproof in the aftermath of the storm (Emergency Management Australia, 2003). About $31.8 \%$ of the insurance payout was for residential property, $28.6 \%$ for motor vehicle damage, $27.5 \%$ for commercial and industrial property, $5.9 \%$ for aviation, $5.8 \%$ for business interruption and the remainder for marine and other damage claims (Blong et al., 2001; Insurance Disaster Response Organisation, 2005).

Observations of hailstone sizes are available from a survey conducted in the aftermath of the storm by Risk Frontiers, the Natural Hazards Research Centre located at Macquarie University in Sydney (Yeo et al., 1999).

\subsubsection{Sydney thunderstorm December 2001}

A line of severe thunderstorms in the afternoon of 3 December 2001 caused widespread damage with insured losses of approximately AUD 30 million (total estimated costs approximately AUD 130 million) in the Sydney metropolitan area and on the NSW Coast (Emergency Management Australia, 2003). The storms originated in the Blue Mountains, about $90 \mathrm{~km}$ to the west of Sydney and moved east-southeast with an average speed of $80 \mathrm{~km} / \mathrm{h}$. The storms produced moderate hail fall with only a few records of $3 \mathrm{~cm}$ hailstone sizes in and around Pymble (Fig. 1). Rather than a hailstorm, this storm was more a destructive downburst as described by Taylor and Webb (2002) with maximum measured wind gusts of $174 \mathrm{~km} / \mathrm{h}$.

\subsubsection{Sydney hailstorm February 2002}

A damaging supercell passed through the western suburbs of Sydney late in the afternoon of 16 February 2002. It moved in a north north-easterly direction at a speed of about $30 \mathrm{~km} / \mathrm{h}$ accompanied by violent rainfall and severe wind gusts. Only one report of $5 \mathrm{~cm}$ hail, which fell in Merrylands, is available (Fig. 1). This storm caused insured losses of approximately AUD 10 million (Insurance Disaster Response Organisation, 2005).

For the latter two storms, much more limited information in terms of number of reports of a few hailstone sizes and their locations are available from the Australian $\mathrm{Bu}$ reau of Meteorology (BoM) severe thunderstorm database, which also provides information on related severe weather, e.g. wind gusts and flash flooding.

\subsection{Radar}

As indicated above, ground measurements of hailstone occurrence and size are incomplete with usually only a few hailstone sizes and locations recorded. Additionally, hailstones size estimates are prone to exaggeration and commonly based on comparisons with spherical objects such as golf balls, cricket balls, grapes or oranges. By contrast, remote sensing tools, such as radar, provide consistent measurements across large areas with high spatial and temporal resolution and allow accurate comparisons of hail 
characteristics with property damage, though radar provides no information about hailstone size.

Radar data used in this study were obtained from the BoM (Bureau of Meteorology, 2005), which operates the weather watch radar "Letterbox" for storms affecting the Sydney area. This radar is located $60 \mathrm{~km}$ southwest of Sydney on Letterbox Mountain (350 m above sea level) (Fig. 1). The Enterprise Electronics Corporation WSR74 S Band radar operates with an incoherent magnetron transmitter and uses $10.4 \mathrm{~cm}$ radio waves with a $1.9^{\circ}$ horizontal and $1.8^{\circ}$ vertical half-power beamwidth. The typical availability of the nonDoppler radars is $24 \mathrm{~h}$ per day with a $1 \mathrm{~km}$ range resolution and 10 min time steps. Further details can be found in Potts et al. (2000).

Constant Altitude Plan Position Indicator (CAPPI) reflectivities are two dimensional areal representations that are derived from three dimensional sector-volume scans. This horizontal slice is taken through the data at a constant height of $1.5 \mathrm{~km}$, representing a low storm level, close to the surface where hailstones occur. The "cutting method" proposed by Waldvogel et al. (1978) is used to distinguish between hail and rain: radar reflectivities equal to or greater than $55 \mathrm{dBZ}$ are assumed to contain significant hail and lower reflectivities are assumed to be caused mainly by rain. Studies in Switzerland have shown that this threshold corresponds to light damage to crops (Schiesser, 1990) and it has been used as a threshold for estimating damage to automobiles and buildings (Hohl et al., 2002a, b).

In this study, storm paths are derived from successive centroids of the $55 \mathrm{dBZ}$ regions recorded at each 10 min timestep of the $1.5 \mathrm{~km}$ CAPPI reflectivities. This methodology neglects areas of higher reflectivity within the $55 \mathrm{dBZ}$ region but is sufficient for the purpose of defining storm paths. The local time shown on the figures in this paper is Australian Eastern Standard Time (AEST) or Australian Eastern Daylight Time (AEDT), which is 10 , respectively $11 \mathrm{~h}$, ahead of the Universal Time Coordinated (UTC), also known as Greenwich Mean Time (GMT).

\subsection{Hail damage data}

\subsubsection{Insurance claims}

Hail damage to insured property was measured in terms of insurance claims costs, which were provided by a primary insurer for the April 1999 hailstorm. Claims cover residential buildings (single or multi storey dwellings) with damage caused to the interior (e.g. ceiling, insulation, floor or carpet) and exterior structure (e.g. roof, walls, windows).

\subsubsection{Emergency calls and Census data}

The NSW State Emergency Service (SES) provides emergency response and rescue services to NSW communities. The numbers of "requests for assistance" or emergency calls to the SES from individuals for the three storms investigated are listed in Table 1. Due to the magnitude of the April
Table 1. Number of State Emergency Service (SES) requests for assistance and Census dwelling information for investigated storms and their affected Census Collection Districts (CCDs).

\begin{tabular}{|c|c|c|c|}
\hline Storm & $\begin{array}{l}\text { SES } \\
\text { requests } \\
\text { for } \\
\text { assistance }\end{array}$ & $\begin{array}{c}\text { Metropolitan } \\
\text { CCDs } \\
\text { affected }\end{array}$ & $\begin{array}{c}\text { Number of } \\
\text { household } \\
\text { dwellings in } \\
\text { CCDs affected }\end{array}$ \\
\hline April 1999 & 15007 & 645 & 127947 \\
\hline December 2001 & 346 & 100 & 21470 \\
\hline February 2002 & 5274 & 776 & 173227 \\
\hline
\end{tabular}

1999 hailstorm, the NSW Rural Fire Service and the NSW Fire Brigade were also involved in the disaster response and provided additional information. Requests for assistance were screened as far as possible before geo referencing addresses. Nonetheless, deficiencies in data quality may still exist because of incorrect registration of the caller's details (e.g. spelling mistakes of addresses) or multiple entries (with spelling mistakes) from the three different data sources. Importantly, these data also provide valuable information about all properties not just insured properties. Additionally, this information is independent of the variations in market penetration of any one insurance company.

Table 1 also lists the number of metropolitan Census Collection Districts (CCDs) affected by the storms. The 2001 Census of Population and Housing from the Australian Bureau of Statistics provides, among many other things, information on the number of household dwellings, which is listed in Table 1 for CCDs that contain the emergency calls. CCDs provide a finer than postcode resolution in the metropolitan area and urban centres, where an average 212 dwellings per CCD occupy an average area of $0.33 \mathrm{~km}^{2}$ for the storms listed in Table 1.

\section{Results and discussion}

3.1 Spatial distributions of reflectivity, hailstones and emergency calls

Figure 2 shows the most affected area between Botany Bay in the South and Sydney Harbour, including the CBD, for the April 1999 hailstorm. Successive $55 \mathrm{dBZ}$ isolines are derived from the $10 \mathrm{~min}$ radar sequence of the $1.5 \mathrm{~km}$ CAPPI reflectivities and are shown as solid contours for the first cell path (19:23 to 20:13 AEST) and dotted for the second cell path (20:53 to 21:53 AEST). Paths are based on the centroids of these $55 \mathrm{dBZ}$ regions. The $55 \mathrm{dBZ}$ regions or hail cells merge and split and eventually dissipate or move out to sea as described in the Bureau of Meteorology Technical Report (2005).

There is good agreement between the areas $\geq 55 \mathrm{dBZ}$ and reported hail cover on the ground (as represented by the largest hailstone sizes) (Fig. 2a) as well as locations of 


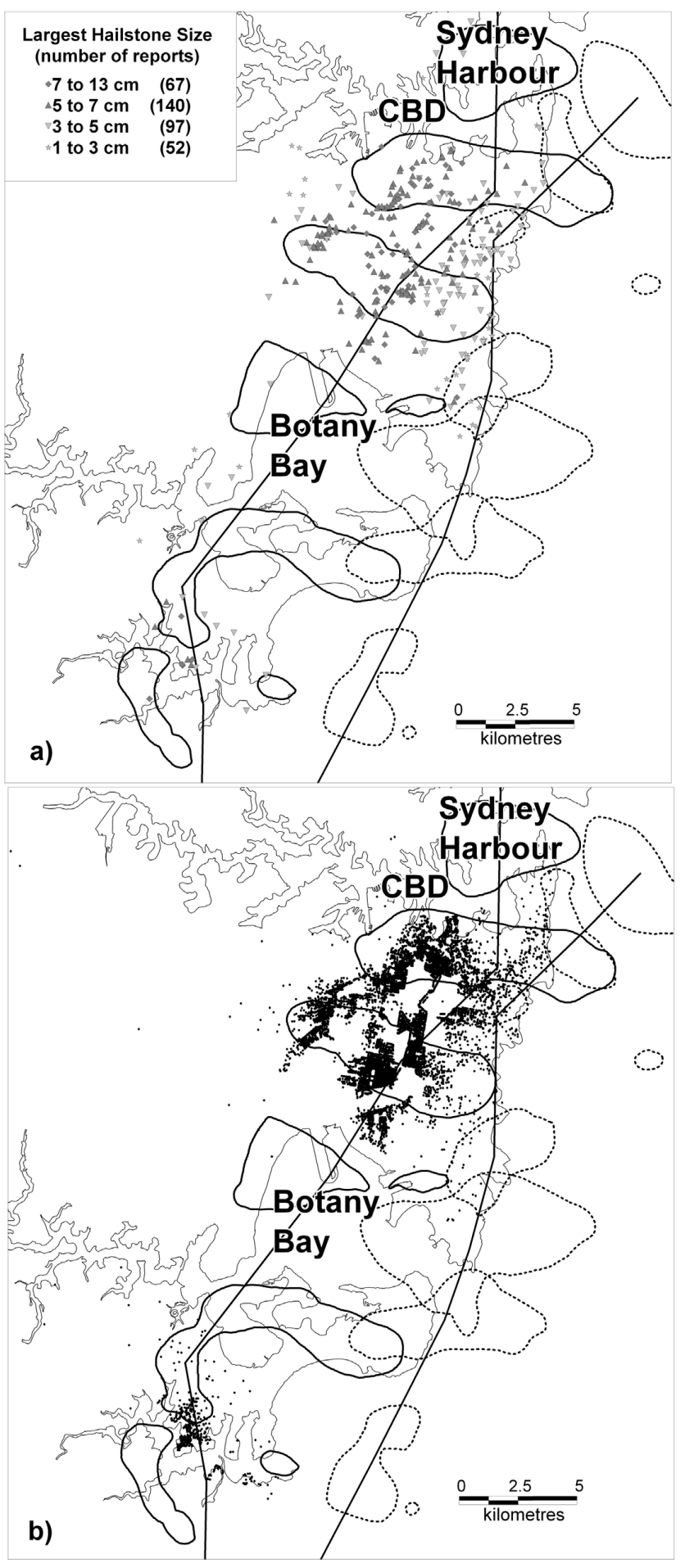

Fig. 2. Affected areas and storm paths derived from successive centroids of the $55 \mathrm{dBZ}$ areas with (a) hailstone sizes categorised according to their diameters in $\mathrm{cm}$ and (b) SES "requests for assistance" for the April 1999 hailstorm. Successive 55dBZ isolines are derived from the $10 \mathrm{~min}$ radar sequence of the $1.5 \mathrm{~km}$ CAPPI reflectivities and are shown as solid contours for the first cell path (19:23 to 20:13 AEST) and dotted for the second cell path (20:53 to 21:53 AEST). emergency calls (Fig. 2b). Both figures show areas with no data to the north of Botany Bay; these correspond to the location of Sydney's major airport and surrounding areas mainly occupied by commercial buildings and hangars. At the time of the storm most of these businesses would have been closed; it is also likely that these businesses were selfsufficient and did not require SES support. A few empty patches are also noticeable during the next two successive $55 \mathrm{dBZ}$ time steps located directly over the densely populated area between the CBD and Botany Bay. These correspond to a racecourse, a sporting arena as well as several large parks.

The largest hailstones were reported to the left of the first storm cell path (Fig. 2a). This is consistent with the position of the strongest updraft particularly evident in supercell thunderstorms (Browning, 1985; Moller, 2001). Smaller hail observed closer to the coast is likely to have fallen from hail cells belonging to the second storm path. A previous study of the April 1999 hailstorm used the percentage of damaged roof from individual buildings as an indicator for the damage, with $100 \%$ indicating total roof damage to a single property. Similarly, results identified the location of individual buildings with major roof damage ( $\geq 70 \%)$ to the left of the path and in good agreement with areas experiencing larger hailstones (Schuster and Blong, 2004).

It seems fair to assume that the damage would have been higher if the hailstorm had occurred further west. This can be explained due to less open spaces (e.g. no major airports, parks) in the more western suburbs and hence higher housing density. Part of the hail cells moved over the ocean (especially the second cell); if the hailstorm had been located only slightly further west, the damage could have drastically increased. Another dramatic scenario would be if the second hail cell had passed closer to the damage path of the first hail cell, subjecting already damaged property to even more water damage and possibly collapsing ceilings. Implications for emergency management institutions could have been far worse in both scenarios.

Hailstorm loss modelling indicates that higher losses could indeed have been generated by storms with the same maximum hailstone size and damage footprint as the April 1999 storm, but with different locations and orientations. Of 50000 such simulated storms, the largest modelled loss was 50\% larger than the actual loss (Kuhnel and Leigh, 2000). The situation is complicated due to part of the actual storm being over the ocean. The assumption about footprint size used in the modelling is likely to be conservative.

3.2 Storm path and spatial distributions of the emergency response intensity

To analyse the spatial distribution of the "requests for assistance" (Fig. 2b) in a more quantitative way, the number of emergency calls as a proportion of the total number of dwellings in a CCD was examined. This variable, referred to as the "emergency response intensity", can be considered as a measure of storm intensity or hail severity. 


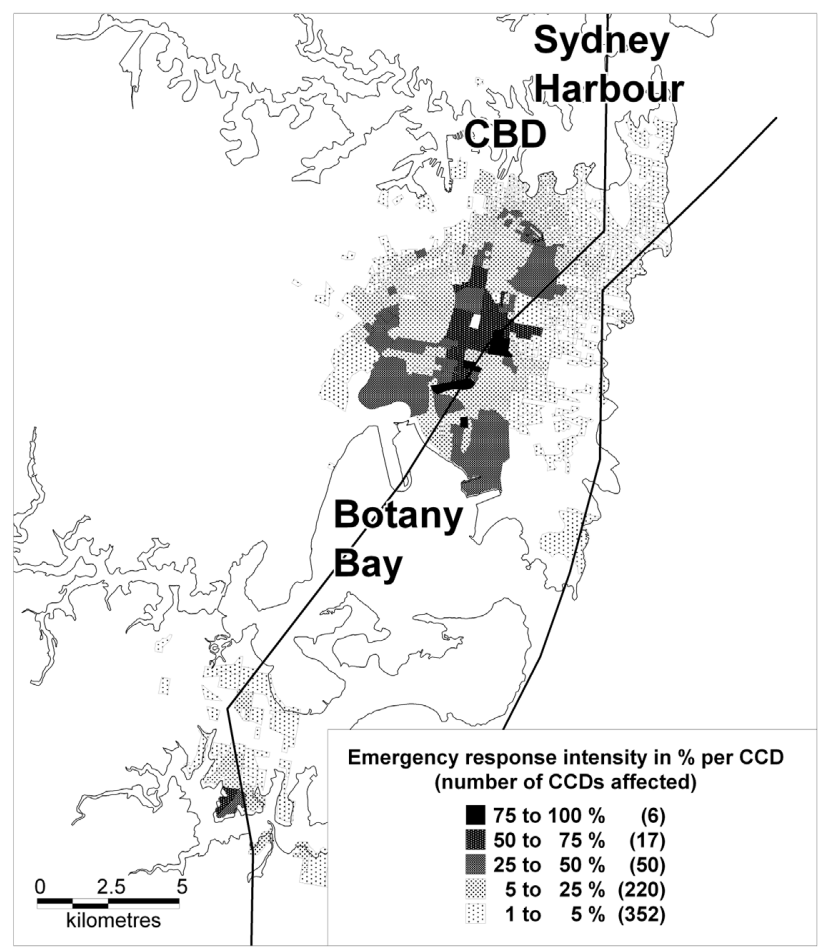

Fig. 3. Emergency response intensity (percentage of homes per CCD requesting assistance) along with the storm path for the April 1999 hailstorm.

Results for 645 CCDs impacted by the April 1999 hailstorm are shown in Fig. 3. Areas of highest emergency response with 50 to $100 \%$ of households calling for emergency help are located directly under the storm path with a slight tendency towards the left of the path. This spatial feature of the emergency response intensity corresponds well with larger hailstone sizes and the percentage of roof damage located to the left side in relation to the storm movement as mentioned earlier. Over half of the affected CCDs experienced emergency response intensities between 1 and 5\%; the majority of these are located within the envelope of the storm especially in the eastern suburbs between the two storm cell paths.

Figure 4 shows an equivalent plot to Fig. 3 for the northern damage path of the multicell storm of December 2001. Again, there is good qualitative agreement between the $55 \mathrm{dBZ}$ area and the location of the emergency calls for this storm (not shown).

Compared to the April 1999 hailstorm, wind gusts in the December 2001 storm were more severe and the thunderstorm speed much faster. Moreover, this storm produced only moderate sized hail on the ground with a few reports of $3 \mathrm{~cm}$ hailstone sizes in and around Pymble (location shown in Fig. 4). Hailstone size is influenced by a number of factors, e.g. instability and wind shear, as well as the topography and the height of the $0^{\circ} \mathrm{C}$ isotherm. This distance influences the time for melting during hail fall. The $0^{\circ} \mathrm{C}$ isotherm was much higher during this storm $(4.2 \mathrm{~km})$ compared to the April 1999

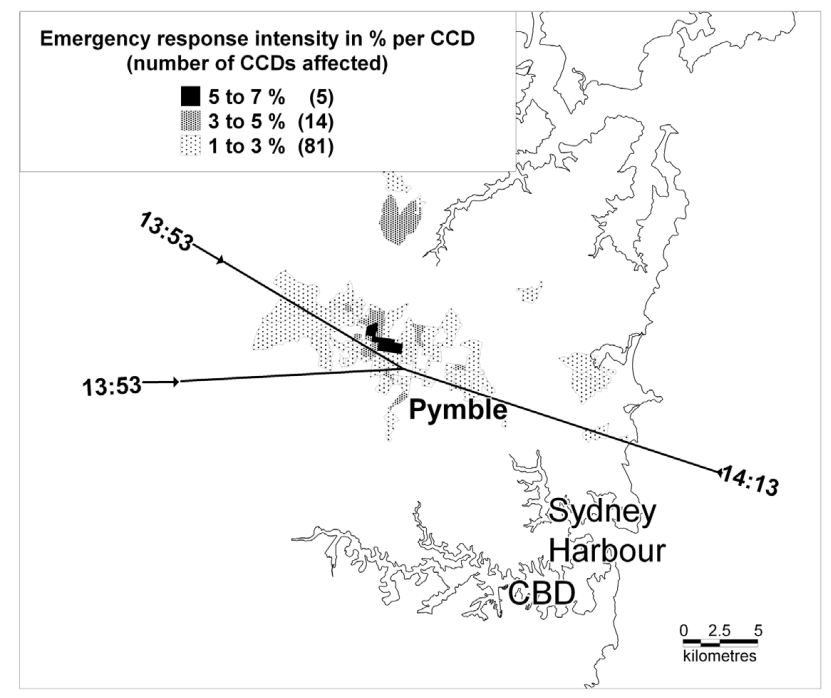

Fig. 4. Emergency response intensity (percentage of homes per CCD requesting assistance) for the December 2001 storm. Location of reported hailfall (Pymble) is indicated and local time (AEDT) of the radar defined storm path is given.

hailstorm $(2.8 \mathrm{~km})$. Additionally the surface air temperature was very high $\left(T=40^{\circ} \mathrm{C}\right)$. Moderate-sized hail is probably the main reason for small values of the emergency response intensity up to $7 \%$, compared to the other storms.

The CCDs with the most intense emergency response are again clearly located to the left relative to the storm path. This is in agreement with previously analysed insurance claims for this storm, which indicated that most of the damage was caused by destructive wind gusts. Although only a few claims mention hail as the primary cause of damage, other damage may also have been caused by hail. Although this storm was more a windstorm than a hailstorm, hail damage is still concentrated to the left of the storm path (Schuster and Blong, 2004). It is unlikely, however, that the cell in question was a supercell as stated earlier.

Substantially higher emergency response intensity consistent with more and costlier damage data in the insurance claims can be seen where the paths of the two storm cells merge. This may be explained due to increased available energy as a result of the intensification of the updraft region causing hailstone dimensions to increase (Nelson, 1987). It has also been suggested that a seabreeze boundary played a role in intensifying the cells in question (Webb, R., personal communication, 2005). The CCD $10 \mathrm{~km}$ north of the merging point with moderate emergency response intensity of up to $5 \%$ can be attributed to a small convective cell development.

The path of the supercell storm of February 2002 along with the corresponding emergency response intensity is shown in Fig. 5. For this storm, the area $\geq 55 \mathrm{dBZ}$ covers the majority of the southern damage area. However, to the north, damage is spread much more widely to the left of the storm track and in some parts was not entirely captured by the area $\geq 55 \mathrm{dBZ}$ (not shown). Doppler radar imagery of this 


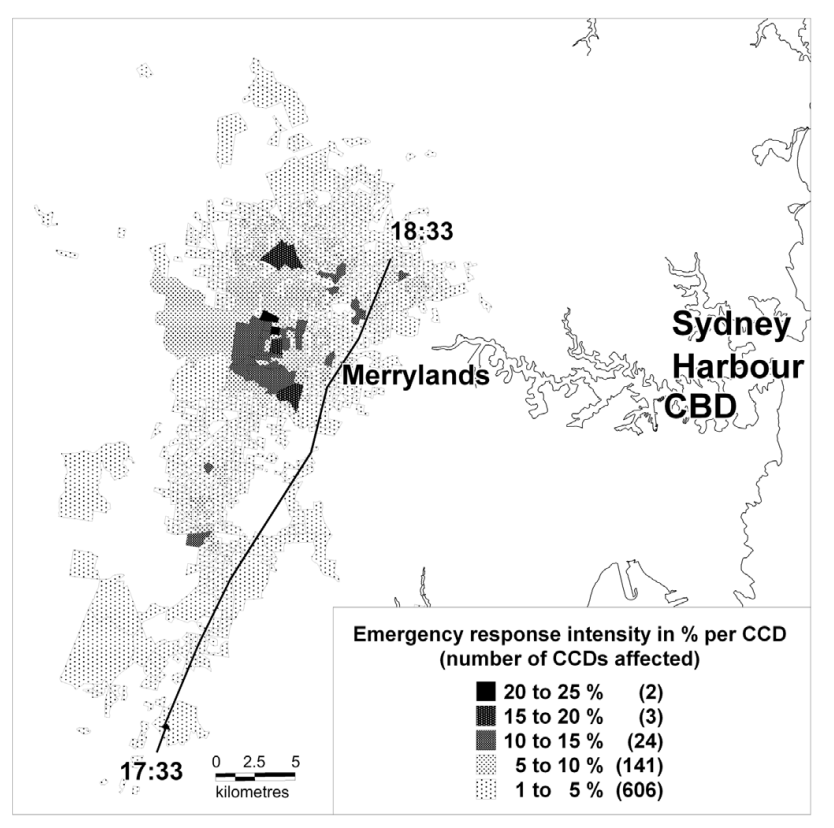

Fig. 5. Emergency response intensity (percentage of homes per CCD requesting assistance) for the February 2002 storm. Location of reported hailfall (Merrylands) is indicated and local time (AEDT) of the radar defined storm path is given.

event suggested a wide area of damaging winds away from the high reflectivity core. This is not uncommon for wind producing supercells. The damage from this event was also exacerbated by antecedent rainfall (Webb, R., personal communication, 2005). Nonetheless, the location of the damage is again clearly to the left of the storm path. The emergency response intensity with maximum values of up to $25 \%$ lies in between values of the December 2001 and April 1999 storm. This is presumably due to the intermediate hail size observation (maximum of $5 \mathrm{~cm}$ was reported in Merrylands).

\subsection{Emergency response intensity and hailstone size}

The maximum hailstone size is the most commonly measured variable and is more closely correlated with damage to structures than is either the modal hailstone size or number of hailstones per unit area (Changnon, 1977; Smith and Waldvogel, 1989; Bardsley, 1990). This is reasonable given that the kinetic energy of a hailstone is proportional to the fourth power of its diameter, using Newton's second law of motion with the vertical velocity of spherical hailstones near the surface after Matson and Huggins (1980). Horizontal wind gusts will also increase the terminal velocity and ultimately the impact kinetic energy.

A promising correspondence between the spatial distributions of the emergency response intensity and hailstone sizes was implied in Figs. 2 and 3. For a more quantitative assessment, the largest hailstone per CCD was extracted along with requests for assistance. Figure 6 shows the average emergency response intensity together with standard deviations against hailstone size. Large standard deviations were trun-

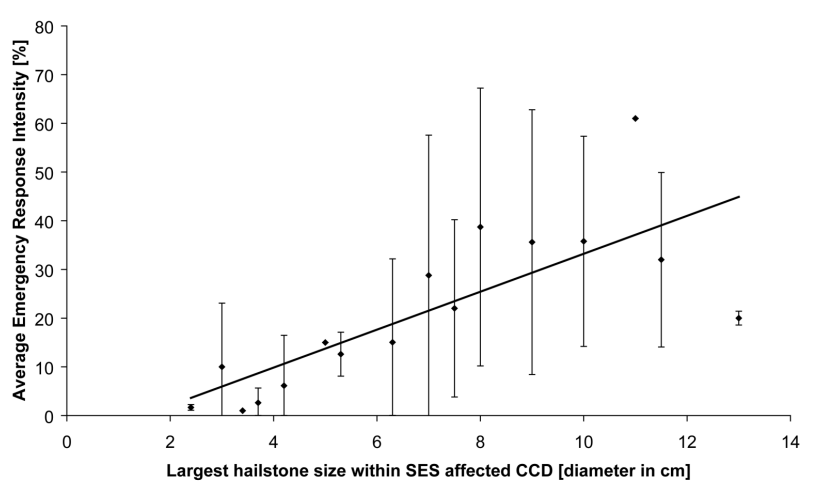

Fig. 6. Average Emergency Response Intensity versus largest hailstone size per CCD for the April 1999 hailstorm $(N=167)$. Error bars show one standard deviation either side of the mean.

cated at zero to avoid implying negative emergency response intensities; this feature is indicative of skewed damage distribution as is common with many other natural hazards.

Figure 6 suggests a damage threshold of hail impacting buildings for hailstone sizes around $2.5 \mathrm{~cm}$. Beyond $6 \mathrm{~cm}$, the data exhibits a fairly dramatic increase in the variance of the emergency calls. This may indicate another damage threshold, likely associated with much more severe damage, warranting the assistance of the emergency services. Those findings are consistent with occupants' description of roof damage associated with various maximum hailstone sizes as collected in the original survey (Yeo et al., 1999). Analysis of these data indicated that hail smaller than $3 \mathrm{~cm}$ rarely damaged roofs or windows whereas hail greater than $5 \mathrm{~cm}$ caused substantial damage (as defined by "many broken tiles" in over $50 \%$ of responses).

A linear regression analysis from this comparison results in a correlation coefficient of $r=0.77$ when all hailstone sizes are considered. If we assume that the maximum hailstone size recorded by a professional observer $(9 \mathrm{~cm})$ was correct and that reports of larger stones are exaggerations and should be ignored, the correlation increases to $r=0.93$. However, acceptance of this assumption presumably means that all hailstone values and the threshold values identified above require adjustment.

A ramp or logistic function might provide more insight to likely damage thresholds than a linear relationship. The emergency response intensity may be insensitive to increases in hailstone diameters beyond $8 \mathrm{~cm}$.

\subsection{Insurance claims and hailstone sizes}

The average cost of individual building claims per CCD was calculated and plotted against the largest hailstone size. This is shown in Fig. 7 together with the standard deviations, which were also truncated at zero for some values. Linear regression analysis results in a correlation coefficient of $r=0.68$.

Figure 7 indicates that the threshold of hail causing damage to insured buildings starts at hailstone sizes of around 


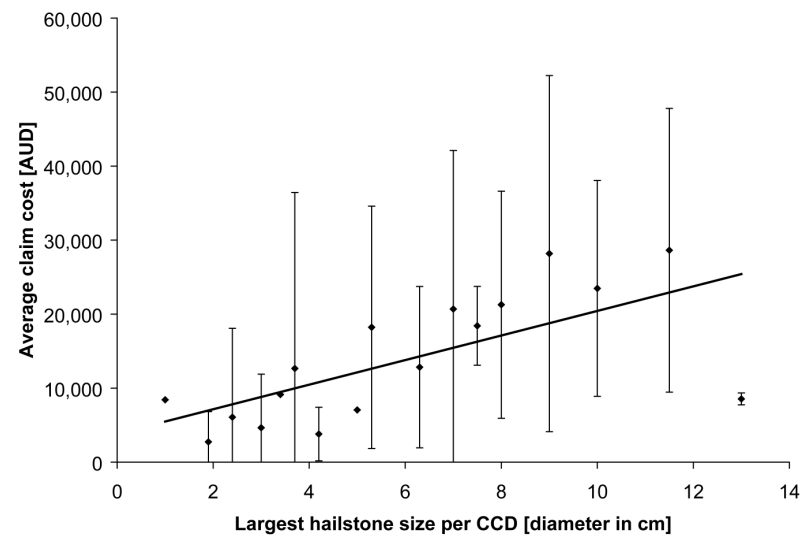

Fig. 7. Average claim cost versus maximum hailstone size per CCD for the April 1999 hailstorm $(N=160)$. Error bars show one standard deviation either side of the mean.

$1 \mathrm{~cm}$. This is smaller than the hailstone size of $2.5 \mathrm{~cm}$ indicated on Fig. 6. Such damage is likely to be minor and caused by hail-susceptible building parts, e.g. skylights, windows, awnings or fences or may be caused due to water ingress from blocked drains or the weight of small hail on weak structures. Blong (1997) and Blong et al. (2001) claim that hail smaller than $2 \mathrm{~cm}$ can cause damage, especially when wind driven; Fig. 7 indicates that this might be the case.

There is a high variance of the average claim cost with all hailstone sizes and not only for hailstones $>5 \mathrm{~cm}$. This indicates significant variability in building material vulnerability.

\subsection{Emergency response intensity and average insurance claims}

Based on a claims survey for all insurance companies by the Insurance Disaster Response Organisation (2005), an average insurance claim paid of AUD 12300 for residential building and content policies was calculated for the April 1999 hailstorm. For further analysis, insurance claims (provided for this study by one primary insurer) were averaged for affected CCDs. Only averages based on two or more claims per CCD were considered with one average claim above AUD 60000 being omitted. The majority of claims produced costs below AUD 15000, with the most frequent claim category between AUD 5000 and AUD 7500 (Fig. 8).

The skewness in the frequency towards smaller claim costs is also noticed in the relation between the emergency response intensity and the derived average claim cost, as shown in Fig. 9. A linear regression analysis from this comparison results in a correlation coefficient of $r=0.69$, indicating that higher claim costs occurred in CCDs that experienced a higher emergency response intensity and vice versa. Areas with a high percentage of damaged houses produced average higher claims costs. This result accords with the positive correlations between both higher emergency response intensity and claims costs with larger hailstone sizes.

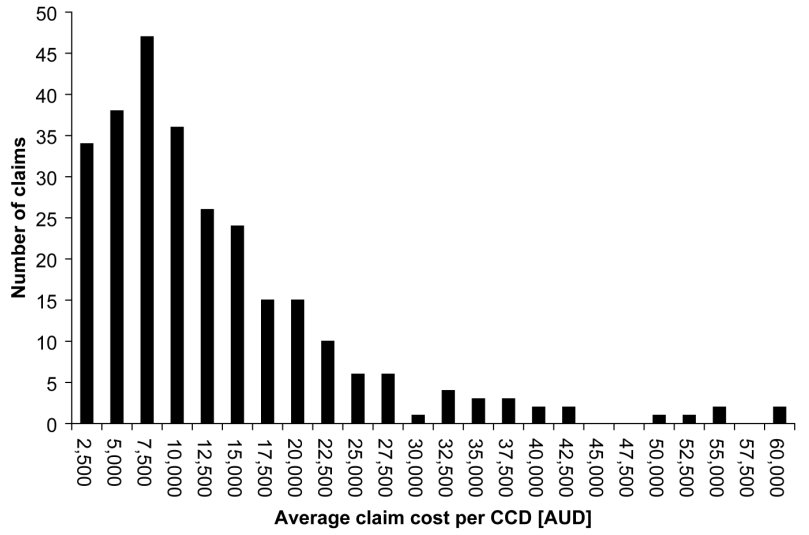

Fig. 8. Histogram of the average insurance claim paid per CCD for the April 1999 hailstorm.

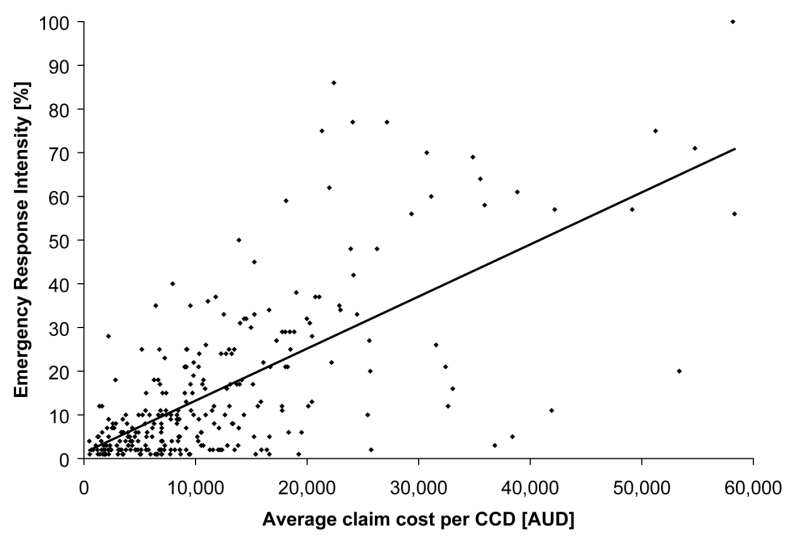

Fig. 9. Emergency Response Intensity versus average claim cost per CCD for the April 1999 hailstorm. Only averages with two or more claims are considered.

\section{Conclusions}

The 14 April 1999 Sydney hailstorm and its impacts is analysed in detail in this study. Results are based on hazard information (hailstone size observations and weather radar) and damage data (emergency calls and insurance claims).

Proxy information for hail damage to buildings in the form of "requests for assistance" indicates a good spatial correspondence with the radar-derived reflectivity area $\geq 55 \mathrm{dBZ}$. The area of high reflectivity covers most of the hailfall that was reported in a survey of the Sydney April 1999 hailstorm. Two storm cases investigated in this study support the view that the area $\geq 55 \mathrm{dBZ}$ is a good approximation of the hail swath. In all cases the preferred area for severe hail damage is clearly located to the left side of the storm path. The area of the emergency response intensity corresponds well with larger hailstone sizes and more severe roof damage for the April 1999 hailstorm. In another storm, CCDs containing the highest emergency response intensity are located at the point of merger of two convective cells. Values of the emergency response intensity correspond well to maximum hailstone sizes for the three storms. 
Based on a comparison between the emergency response intensity and hailstone sizes, a damage threshold of hail impact on buildings can be identified for hailstone sizes around $2.5 \mathrm{~cm}$. Another damage threshold for hailstone sizes $>6 \mathrm{~cm}$ is associated with more severe damage. In comparison, the threshold of hail causing insured claims starts at hailstone sizes of $1 \mathrm{~cm}$. A high variance of the average claim cost is likely to be a reflection of high variability in the vulnerability of different building materials. The emergency response intensity and the claims cost correlate positively with hailstone sizes. Higher claim costs occurred in CCDs that experienced higher emergency response intensities.

Relationships that might lead to the operational use of radar as an early indicator after the event of expected damage, which would be of value to insurance companies and assist in the despatch of emergency services, remain to be investigated in Australia. The high variance of the data is not surprising as the impact on buildings of other natural hazards, such as earthquakes, floods and bushfires are similarly variable. Further work, better and more data are required to improve these results. Nevertheless, our preliminary results are promising and will hopefully encourage further research in this area.

Acknowledgements. Our gratitude is expressed to the NSW SES for providing the requests for assistance (A. Gissing and P. Crowe) and the Bureau of Meteorology Research Centre for providing the radar data and software (special acknowledgements to R. Potts and A. Seed). We are very grateful to the primary insurer who provided insurance damage data as well as uncomplicated and friendly assistance. We also thank L. Hunter, P. Somerville, R. Webb, J. Seltmann and T. Grollmann for their respective contributions to this manuscript. The Australian International Postgraduate Research Scholarship and the Macquarie University International Postgraduate Research Award funded this research.

Edited by: U. Ulbrich

Reviewed by: T. Grollmann, J. Seltmann, and R. Webb

\section{References}

Bardsley, W. E.: On the Maximum Observed Hailstone Size, J. Appl. Meteorol., 29, 1185-1187, 1990.

Blong, R. J.: Thunderstorms as Insured Hazards, in: Conference Proceedings, Financial Risk Management for Natural Catastrophes, edited by: Britton, N. R. and Oliver, J., 59-84, 1997.

Blong, R. J., Leigh, R., Hunter, L. and Chen, K.: Hail and Flood Hazards - Modelling to Understand the Risk, in: Conference Proceedings, Enhancing Shareholder Value Through Capital Risk Management, edited by: Britton, N. R. and Oliver, J., 25-39, 2001.

Browning, K. A.: Morphology and Classification of MiddleLatitude Thunderstorms, Chapter 7. "Thunderstorms: A Social, Scientific, and Technological Documentary, Volume II, Thunderstorm Morphology and Dynamics", edited by: Kessler, E., University of Oklahoma Press, Norman, 2, 133-152, 1985.

Bureau of Meteorology: Australian Weather Watch Radar home page, http://mirror.bom.gov.au/weather/radar, 2005.

Bureau of Meteorology Technical Report: The 14 April 1999 Sydney Severe Hailstorm, in press, 2005.
Changnon, S. A.: The Scales of Hail, J. Appl. Meteorl., 16, 626648, 1977.

Changnon, S. A. and Burroughs, J.: The Tristate Hailstorm: The Most Costly on Record, Month. Wea. Rev., 131, 1734-1739, 2003.

Emergency Management Australia: EMA Disaster Events Data Tracking System (EMATrack), http://www.ema.gov.au/ema/ emaDisasters.nsf, 2003.

Heimann, D. and Kunz, M.: The Munich hailstorm of 12 July 1984: a discussion of the synoptic situation, Beitr. Phys. Atmos, 58, 528-544, 1985.

Hohl, R., Schiesser, H.-H., and Aller, D.: Hailfall: the relationship between radar-derived hail kinetic energy and hail damage to buildings, Atmos. Res., 63, 177-207, 2002a.

Hohl, R., Schiesser, H.-H., and Knepper, I.: The use of weather radars to estimate hail damage to automobiles: an exploratory study in Switzerland, Atmos. Res., 61, 215-238, 2002b.

Insurance Disaster Response Organisation: Major Disaster Event List Since June 1967 (revised to February 2005), http://www. idro.com.au/disaster_list/default.asp, 2005.

Kuhnel, I. and Leigh, R.: Pricing hail losses: extrapolation of past losses versus stochastic modelling, Natural Hazards Quarterly, 6/1, 1-4, 2000.

Matson, R. J. and Huggins, A. W.: The Direct Measurement of Sizes, Shapes and Kinematics of Falling Hailstones, J. Atmos. Sci., 37, 1107-1125, 1980.

Moller, A., R.: Severe Local Storms Forecasting, Chapter 11. "Severe Convective Storms, Meteorological Monographs", edited by: Doswell, C. A., American Meteorological Society, Boston, 28, 433-480, 2001.

Munich Re: Hailstorm, Munich Reinsurance Company, Munich, Germany, 56, 1-56, 1984.

Nelson, S. P.: The Hybrid Multicellular-Supercellular Storm - an Efficient Hail Producer. Part II: General Characteristics and Implications for Hail Growth, J. Atmos. Sci., 44, 2060-2073, 1987.

Potts, R. J., Keenan, T. D., and May, P. T.: Radar Characteristics of Storms in the Sydney Area, Month. Wea. Rev., 128, 3308-3319, 2000.

Schiesser, H.-H.: Hailfall: the relationship between radar measurements and crop damage, Atmos. Res., 25, 559-582, 1990.

Schuster, S. S. and Blong, R. J.: Hailstorms and the Estimation of their Impact on Residential Buildings using Radar, Conference Proceedings, Sixth International Symposium on Hydrological Applications of Weather Radar, 7 pp., 2004.

Schuster, S. S., Blong, R. J., and Speer, M. S.: A Hail Climatology of the Greater Sydney area and New South Wales, Australia, Int. J. Climatol., in press, 2005.

Smith, P. L. and Waldvogel, A.: On Determinations of Maximum Hailstone Sizes from Hailpad Observations, J. Appl. Meteorol., 28, 71-76, 1989.

Taylor, J. C. and Webb, R. M.: 3 December 2001 - Environmental and Radar Characteristics of a Destructive Downburst, Conference Proceedings, Bureau of Meteorology, Australia, Internal Conference, 2002.

Waldvogel, A., Federer, B., Schmid, W., and Mezeix, J. F.: The Kinetic Energy of Hailfalls. Part 2: Radar and Hailpads, J. Applied Meteorol., 17, 1680-1693, 1978.

Yeo, S., Leigh, R., and Kuhnel, I.: The April 1999 Sydney Hailstorm, Austral.. J. Emer. Manag., 14, 23-25, 1999.

Zillman, J.: Report by the Director of Meteorology on the Bureau of Meteorology's Forecasting and Warning Performance for the Sydney Hailstorm of 14 April 1999, 35 pp., 1999. 